1）炤和 8 年度全職業死亡總數ハ1, 193, 987 人 (內男 618,496 人，女 575,491 人ナリ) =シ テ，其中デ醫療二從事スル所謂醫療屬ノ死亡 數入 3,712 人 (内男 2,319 人，女 1,393 人ナリ) ナリ。死因别二之 7 見ル二呼吸器，結核二依 テ死亡スル者最モ高率 $ヨ$ 示シ，即チ $161.6 \%$ (内男 $136.2 \%$ ，女 $254.1 \%$ リ) 二達セル リタリ。次デ多キハ腦出血（腦栓塞, 腦血栓 含么) ニシテ，㴧チ $121.2 \%$ (內男 $162.1 \%$ ，女 $53.1 \%$ ナリ ヨ示ス 7 知リタリ。又男女別二 於テ腦出血八呼吸器, 結核二比シ男, 霍患率 著シク高キヨ知ル。

2）人口 10 萬以上八市二於テハ, 其全職業 死亡總數 238,011 人 (內男 126,337 人，女 111 , 670 人ナリ) =シテ，醫療屬，死亡數、 1,097 人 (内男 693 人，女 404 人ナリ) 二達シタリ。 死因別ニ之ヨ見ル二結核, 死亡率著シク高率 ヨ示シ,實二 $179.5 \%$ (內男 $150.0 \%$ ，女 230.1

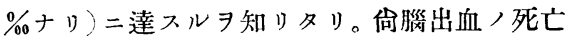
率八 $121.2 \%$ (内男 $152.8 \%$ ，女 $66.8 \%$ ナり) ヨ示シタリ。結核ハ女二多ク, 胹出血八男二 多キヨ知リ得ベシ。

3）醫療蠋中直接醫療二從事スル者（師チ 有業者) 卜家族卜ノ區別 7 見ル二, 結核八家族 二少ク直接醫療二從事スル者二著シク多キヨ 知リタリ。又腦出血八殊二直接整療二從事ス ル者ノ男二著シク多キハ注目二價スベシ。師 于結核八有業者八 $156.2 \%$ (內男 $126.1 \%$ ，女 $208.3 \%$ リ ) ニシテ，家族ハ $57.0 \%$ (內男 $59.4 \%$ ，女 $55.1 \%$ ナリ 7 示ス。又腦出血八 有業者八 $117.0 \%$ (內男 $156.2 \%$ ，女 $51.6 \%$ ナリ) ニシテ，家族八 $76.1 \%$ (內男 $58.9 \%$ ，女 $87.5 \%$ ナリ) ヨ示シタリ。

4) 又更二年齢階級別二死因 7 見ル二, 結 核ハ 20 歲ヨリ 40 歲マデが最モ著シク，腦出 血八 40 歳ヨリ漸次上昇シテ 60 歳乃至 80 歲二 於テ最上點二達ス。演者が第 1 報二於テ報告 シタル齒科醫師，年撂階級別死亡，曲線卜結 核ノ年齢階級別死亡曲線卜彷佛タル八齒科醫 師ノ死亡が結核卜關係淺カラザルヨ思ハシム
ルモくナリ。

5）要スル二直接醫䝤ニ從事スル職業人ハ 先ヅ結核二犯サレル危險が最モ高ク，コノ危 險期 7 越スヤ, 今度八腦出血，危險期二入ル ワタデ，㠫人八覧業二精稀スルト同時二健康 ニモ細心ノ注意 要スルヤ必然ナリ。(自抄)

追 加

弓 倉 繁 家

我が教室，可兒八Impression 後, Plas-

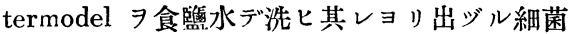
ノ多キニ警イテキル。齒科醫が卒業後約 10 年デ死ヌ樣デ八，傳染ヨ防グ意味デ，是非 Impressionmodel ヨモ消毒スル必要がアル。 更二可兒ハ「フォルマリン」瓦斯消毒シテ, 無處 置ノモノト比シテ落明ナル差異アルヨ見テキ ル。

\section{9. 齒牙ノ熱處理二對スル研究} （第四包報告）

(熱處理二於ケル人類，猿大類，齒牙 ノ顯微鏡的觀察二就テ)

本野賢二(阪大蒛科)

余八前 3 囩二涉り人類及諸動物，齒牙加熱 二依ル顛末及人類卜動物, 差異 7 比較報告七 リ。以上，實驗 ヨリシテ操作最モ困難ナル加 熱後ノ硬組織 $ョ$ リ各固有組織構造 $\exists$ 顯微鏡下 二磪證シ以テ其ノ耐熱性ノ如何二强キカ 7 知リ 得タリ。今义人類及猿犬, 加熱後ノDentinkanälchen，相異點 $\exists$ 指摘鑑別 シ以テ本研究， 結末卜ス。和田博士八人類及諸動物, 管狀骨 橫斷面二於テ Havers 氏細管,太サ, 數 7 論究 シ人八動物二比シ口舜大且ツ其ノ數少シト結 論七ラレタリ。余八蓮牙, 固有組織構造タル

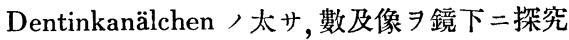
シ以テ兩者 鑑别ニ資セントス。抑々正常ナ ル Dentinkanälchen, 口僢八諸先輩, 成績二 依レバ Oschinsky 氏 $3.2-1.2 \mu$, Kölliker 氏 $2.2-1.3 \mu$ ，Römer 氏 $1.0 \mu$ ，安澤氏 $2.3 \mu$ 。 今之ヨ加熱二依リ起ル變化ハ多種多樣ナラン モ一定條件(同量, 同溫, 同部, 同染色) = 處理スルトキ八略、各固有ノ變化 7 發見シ得 ル信念二基キ實驗二着手セり。實驗材料人 
類蓄牙八當大學病理學教室ヨリ惠マレタル19 歳一5 歳, 23 體ヨリ得タルモ, 猿ノ蒛牙八 2 歲一 5 歳卜推定サル、モ，4頭，犬／兽牙 八2歳一6歲卜推測サル、モ, 各外觀健全ナ ルモノヨ實驗二供セリ。實驗方法 一蒛牙二 於ケル一定部位及苜細管, 最モ正確二近キ橫

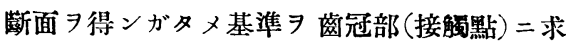
又約 $100 \mathrm{mgr}$ >重量二鋸斷入。後電氣爐中二處 理スルトキ八約 12 分 10 秒內外 $=$ テ $\mathrm{F} 1800^{\circ}=$ 加熱スル事ヨ得ベシ。斯クシテ得タル檢體 充分ナル水洗二依り萊雜物, 除去及ビGelatin 銀膠留㴆潤, 還元, 固定後 Try Compound= 包埋研磨シテ標本，製作 $コ$ 終ル。實驗成績 以上, 如クシテ得タル標本 $尹$ Ultrapak 装置二 檢鏡スル時ハ750倍ニテ人類，Dentinkanälchen 八太キ黑色環狀 7 呈 シ中央部八基質部卜同色 ヨ見ル二比猿及大八充實性，黑點トシテ現 ハレ基質部卜八限界明暸ナラブ。此, 現象 探索スルタメ處理前二於ケル兩組織, 銀染色 ヨ行ヒ檢鏡セル二處理後卜略?一致スル像 見タリ。コレ兩組織, 組織構造二依ルNeumann' sche Scheide =關係スルモノナランカ或入 Gelatin 銀劑/性質二起因スルモノナルカ 侗木追究习必要卜ス。Dentinkanälchen，太 サ及ビ數八其, 部位的差晎 7 供フモノニシテ 一定, 基準部位二依ラザルぶカラブ。故二蒛 牙二玷テハ蒛冠膨隆部，横斷面二於テハ約髓 腔 $>$ 附近，中央部，表層部八三部位二基準 7 定メ精細二調查セルニ表示, 如シ。兩者/比 ヨ最モ簡單二且ッ解シ易ク檢鏡其, 儘 $\ni$ 表記 スレバ, 人類 Dentinkanälchen，數 Okular Nezmikrometer $0.5 \mathrm{~mm}$. Okular $15 \times$ Objektive $50 \times$ 本均 8 個。猿, Dentinkanälchen 八數本均 15 個。猿八丁度人類, 2 倍卜知ル事 ヨ得タリ。Dentinkanälchen ノ太サ八正磪ナ ル縱横断面ヨ必要トスレドモ同一標本二於テ 全面ノ正確二近キ橫面面习得ルコトハ不可能 ナルヨ以テ比較的得易キ髓䏶附近，中央部， 二部位二基準 7 定メ各部 5-6個 7 嚴選測定七 ルニ表示ノ如シ。人類 Dentinkanälchen，日
䱏 $2.82 \mu$, 猿，Dentinkanälchen $1.86 \mu$ 。以上 八成績ハ F 1800 度二加熱七ル場合，㡙細管， 口徑及數ニシテ諸學者ノ業績卜ハ全ク其，實 驗方針 $\exists$ 異二ス。又蒛細管, 測定成績八年踰的 變化 基調卜七ズ唯ダ成熟期，退廢期八前牛 二涉テ實驗セルニ過ギブ。犬ノ象牙質八人類 猿二比耐熱度弱ク F 1400 度ニテ早クモ組織 構造二變化 $\ni$ 來タシタメ = Dentinkanälchen ノ檢鏡八不能ナリ，然レドモ斑瑯質八他ノ二 者二比シ F $1800^{\circ}$ 二於テモ冎木組織構造 $\exists$ 存 續入，依テ明二前二者卜鑑別

結論 一定條件,下二比較實驗フルトキ入 $\mathrm{F} 1800^{\circ}$ 二於テ 1. 人類菌細管八猿二比シ太 ク數少ナシ，之骨二於ケル Havers 細管二一 致スルト知ル。2. 蒛細管, 横斷面八人類八 環狀，猿犬類八充實性，黑點卜シテ基質部卜 ノ移行明暸ナラブ。3. 犬, 象牙質、前二者 二比シ耐熱性弱ク依テ來タル溫度的組織變化 ヨ來タスニモカ、ハラズ 珐瑯質八 F $1800^{\circ}=$ テ組織構造ヨ存續スルコト二依リ明二鑑別ス ルコトヨ得ベシ。余八前 3 司二涉リ報告セル 人體硬組織(骨蒛) 人各溫度二於ヶル肉眼的差異 站二兩組織, 檢鏡的鑑別 7 行 上最モ密接ナル關係ヨ有スル他動物齔牙，加 熱後, 變化 $\exists$ 比較シ今又象牙質二縟究入。以 テ鑑定法醫學上及比較解剖學二資セントス。

本研究ヨ完了スルニ當り終始御箵篤ナル御 指導卜御鞭婞 7 賜リタル恩師弓倉教授立应二理 學的方面二涉リ御指導 $ᄏ$ 賜リタル當大學理學 部敉授淺田博士二滿腔八謝意 $习$ 表入。

\section{0. 潩驗徽毒家鬼二於ヶル血液 ノ變化二就テ $\left\{\begin{array}{lll}\text { 高 } & \text { 橋 } & \text { 利 貞(東大齒科) } \\ \text { 土 } & \text { 肥 }\end{array}\right.$}

齒顠口腔領域二於ヶル炎症性疾患, 特二急 性症狀 $ᄏ$ 發現シ來ル際二, 血液像 $=$ 變化 7 見 ルハ一般外科的疾患二於ヶルト同樣ナルモ， ニシテ, 其ノ診斷, 補助及ビ治療, 豫後, 指 針トシテ臨牀上重要ナル役ヨ有スル事八周知 八事實ナリ。然ルニ䌅徐ナル經過ヨ取リテ發 